\title{
Genetic structure and diversity of two highly vulnerable carcharhinids in Australian waters
}

\author{
Pascal T. Geraghty ${ }^{1,2, *}$, Jane E. Williamson ${ }^{1}$, William G. Macbeth ${ }^{2}$, Dean C. Blower ${ }^{3}$, \\ Jess A. T. Morgan ${ }^{4}$, Grant Johnson ${ }^{5}$, Jennifer R. Ovenden ${ }^{3}$, Michael R. Gillings ${ }^{1}$ \\ ${ }^{1}$ Department of Biological Sciences, Macquarie University, Sydney, NSW 2109, Australia \\ ${ }^{2}$ NSW Department of Primary Industries, Cronulla Fisheries Research Centre of Excellence, PO Box 21, Cronulla, NSW 2230, \\ Australia \\ ${ }^{3}$ Molecular Fisheries Laboratory, The University of Queensland, St. Lucia, QLD 4072, Australia \\ ${ }^{4}$ Queensland Alliance for Agriculture \& Food Innovation, Centre for Animal Science, PO Box 6097, \\ The University of Queensland, St. Lucia, QLD 4067, Australia \\ ${ }^{5}$ Northern Territory Department of Primary Industry and Fisheries, GPO Box 3000, Darwin, NT 0801, Australia
}

\begin{abstract}
Molecular techniques were employed to investigate genetic structure and diversity in dusky Carcharhinus obscurus and sandbar C. plumbeus sharks in the Indo-Australian region. Tissue samples of 423 C. obscurus and 442 C. plumbeus defined 18 and 11 mtDNA ND4 haplotypes, respectively. For $C$. obscurus, weak genetic differentiation was detected between eastern and western Australian waters (pairwise $\Phi_{\mathrm{ST}}=0.04437, \mathrm{p}<0.008$; pairwise $F_{\mathrm{ST}}=0.02403, \mathrm{p}<0.035$ ), suggesting the delineation of 2 independent populations, while patterns of gene flow between Australia and Indonesia were inconclusive. Rarefaction analysis, however, indicated that robust population comparisons in these species were reliant on sample numbers $>100$ at any particular location. Off Australia's temperate east coast, C. obscurus and C. plumbeus exhibited strong similarities in genetic structure, suggestive of similar evolutionary histories in the region. In addition, genetic validation revealed observers to be highly accurate in the identification of both target species in an eastern Australian shark fishery. Our findings contribute valuable information for the management and conservation of both species.
\end{abstract}

KEY WORDS: Carcharhinidae - Fisheries management - Indo-Pacific $\cdot$ Mitochondrial DNA · Observer accuracy $\cdot$ Population genetics $\cdot$ Stock structure

Resale or republication not permitted without written consent of the publisher

\section{INTRODUCTION}

Topographic, biological and oceanographic limitations to dispersal result in reproductive isolation between groups of individuals. Over evolutionary time, this cessation of (or restriction to) gene exchange leads to quantifiable genetic differentiation as a result of intrinsic natural selection, genetic drift and mutation (e.g. Riginos \& Nachman 2001, Hazlitt et al. 2006). In a context of increasing anthropogenic pressures, the identification of barriers to gene flow can assist with the conservation and management of a species' genetic diversity, which is an essential store of variety if a species is to successfully adapt to future environmental challenges. This is especially pertinent for taxa that are demonstrably vulnerable to human-induced population decline, e.g. elasmobranchs (Stevens et al. 2000, Field et al. 2009).

Sharks have a demonstrated susceptibility to overexploitation on the basis of their life-history traits and a vulnerability to multiple fishing gears (Cortés 2000, Stevens et al. 2000). Recent global increases in commercial fishing effort for sharks have resulted in grave population declines (Baum et al. 2003, Ferretti 
et al. 2008). While magnitudes of stock depletion are disputed (Burgess et al. 2005), there is international agreement regarding the urgent need for the effective management of shark fisheries to address issues of conservation and cascading ecological impacts catalysed by apex predator removal (Barker \& Schluessel 2005, Myers et al. 2007, Ferretti et al. 2010).

The dusky shark Carcharhinus obscurus and the sandbar shark C. plumbeus are 2 large-medium carcharhinid species widely regarded as among the most vulnerable of sharks to overfishing (Smith et al. 1998). As long-lived, late-maturing species of decidedly low productivity (e.g. Simpfendorfer et al. 2002, Dudley et al. 2005, McAuley et al. 2006, Baremore \& Hale 2012, Geraghty et al. 2013), demographic analyses have reported abilities to withstand only very modest levels of fishing mortality in conjunction with slow rates of population increase (Sminkey \& Musick 1996, Smith et al. 1998, McAuley et al. 2007a, Romine et al. 2009).

Nevertheless, being highly sought after for their fins (Clarke et al. 2006), both species are captured in commercial and artisanal fisheries across large parts of their respective cosmopolitan ranges (e.g. Amorim et al. 1998, Castillo-Géniz et al. 1998, McVean et al. 2006, White 2007, Morgan et al. 2009), with poor records of management in some regions. In particular, C. obscurus and C. plumbeus were subject to intense targeted harvest pressure in the now-collapsed large, coastal shark fishery off the east coast of the USA, where various data sets suggest population declines of up to $64-99 \%$ in both species (Cortés et al. 2006, Myers et al. 2007, Baum \& Blanchard 2010). Consequently, both sharks are globally listed by the IUCN as Vulnerable and C. obscurus as Endangered in the north-west Atlantic (Musick et al. 2009a,b).

C. obscurus and C. plumbeus are also important components of commercial shark landings in Australian waters (Simpfendorfer \& Donohue 1998, Macbeth et al. 2009). Dramatic increases in catches off both the east and west coasts led to considerable concern regarding their sustainability under harvest pressure in the region (McAuley et al. 2007a, Macbeth et al. 2009), and emphasised the need for effective management input to arrest further stock decline.

Genetic techniques are useful tools for addressing shark fishery management issues. Population genetic analyses can help identify appropriate scales of management by investigating contemporary patterns of gene flow, genetic diversity and the spatial structure of stocks (Dudgeon et al. 2012). Carcharhiniformes are the most represented of the elasmobranchs in the population genetic literature, but few have been examined in any detail (Dudgeon et al. 2012). These studies have typically focused on elucidating genetic structure over broad spatial scales, consistently demonstrating large oceanic expanses to be robust barriers to mitochondrial gene flow (Duncan et al. 2006, Keeney \& Heist 2006, Benavides et al. 2011a), also in C. obscurus (Benavides et al. 2011b) and $C$. plumbeus (Portnoy et al. 2010). Genetic subdivision on finer scales has also been reported for some shark species, raising important implications for regional fisheries management (Keeney et al. 2003, Karl et al. 2011, Tillett et al. 2012a,b, Whitney et al. 2012).

Previous investigations of genetic structure in $C$. obscurus and C. plumbeus in Australian and neighbouring waters have yielded a variety of results. Portnoy et al. (2010) observed genetic subdivision between eastern and western Australia in $C$. plumbeus based on mitochondrial DNA (mtDNA), while Ovenden et al. (2009) and Benavides et al. (2011b) reported evidence for genetic homogeneity between the same 2 regions in C. obscurus. Ovenden et al. (2009) also raised the possibility of limited dispersal across the Timor Trench in the latter species through a finding of genetic differentiation between western Australia and central Indonesia. The strength of the abovementioned findings, however, was generally limited due to small sample sizes. In light of their vulnerability to population decline, therefore, we believed that a more detailed assessment of genetic structure and diversity was warranted for these 2 species.

Using mtDNA NADH dehydrogenase subunit 4 (ND4) sequence data, we re-assessed the genetic structure of C. obscurus on a regional scale, testing a null hypothesis of genetic homogeneity in IndoAustralian waters, and investigated the genetic diversity of $C$. plumbeus off the east coast of Australia, permitting a comparison with C. obscurus in the latter region. We also applied these genetic data in establishing basic estimates of observer accuracy in an eastern Australian shark fishery, and explored the implications of our findings for the management and conservation of both species.

\section{MATERIALS AND METHODS}

\section{Tissue sample collection}

Shark tissues were collected from a range of locations in Indo-Australian waters (Fig. 1), focusing on a harvested population off Australia's east coast. Tissues were sampled from New South Wales (NSW) 
waters from 2007 to 2010 from landed catch by observers on-board commercial shark-fishing vessels within the NSW Ocean Trap and Line Fishery (NSW OTLF). A small quantity $(<2 \mathrm{~g})$ of white muscle tissue was excised from each specimen, immediately preserved in $95 \%$ reagent grade ethanol, and stored at room temperature. Additional samples, collected from 2000 to 2012, were obtained from more distant locations, including Carcharhinus obscurus and $C$. plumbeus samples from waters of the Northern Territory (NT) in Australia, as well as C. obscurus samples
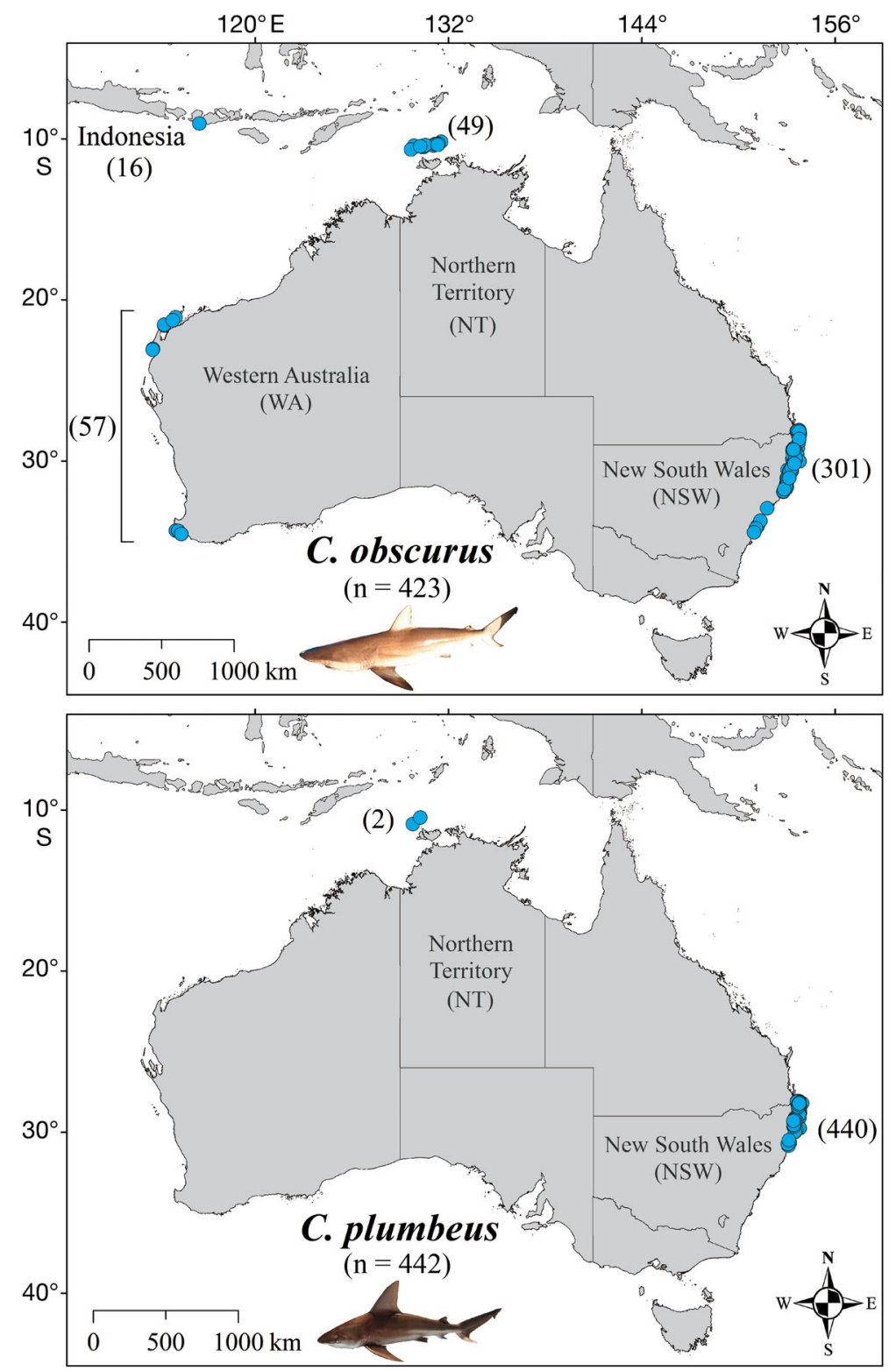

Fig. 1. Collection locations and sample sizes (in parentheses) for Carcharhinus obscurus and C. plumbeus tissues included in genetic diversity and structure analyses from Western Australia (WA) and Indonesia. Samples from NT and WA were collected from landed catch by observers within their respective commercial shark fisheries, and preserved in $20 \%$ dimethylsulphoxide (DMSO) solution and $70 \%$ ethanol, respectively. Samples from Indonesia were collected from landed catch by a fisheries biologist at the Tanjung Luar local market in eastern Lombok, and preserved in $20 \%$ DMSO; exact capture locations were not confirmed. Additional $C$. obscurus tissues were obtained from NSW waters by sampling sharks caught in the NSW Shark Meshing (Bather Protection) Program (Reid et al. 2011). Tissues from NSW and NT were sampled from predominantly adult and sub-adult individuals, while those from WA were sampled mostly from small juveniles. Tissues from Lombok were sampled from processed trunks for which associated length measurements were unavailable.

\section{DNA extraction, amplification and sequencing}

To obtain mtDNA sequence data, total genomic DNA was first extracted from $5 \mathrm{mg}$ of each tissue using a modified salting-out protocol (Sunnucks \& Hales 1996). Samples were digested with $10 \mu \mathrm{l}$ of Proteinase K $(10 \mathrm{mg}$ $\mathrm{ml}^{-1}$ ) in $580 \mu \mathrm{l}$ of TNES (50 mM Tris $\mathrm{HCl}, \mathrm{pH}$ $7.5 ; 400 \mathrm{mM} \mathrm{NaCl}_{i} 20 \mathrm{mM} \mathrm{EDTA}_{\text {; }}$ and $0.5 \%$ SDS) by incubation overnight at $55^{\circ} \mathrm{C}$. Proteins were precipitated by adding $170 \mu \mathrm{l}$ of $5 \mathrm{M} \mathrm{NaCl}$ followed by microcentrifugation at $14000 \mathrm{rpm}$ for $5 \mathrm{~min}$. Supernatant $(600 \mu \mathrm{l})$ was recovered into a fresh tube and the DNA was precipitated by adding $600 \mu \mathrm{l}$ of ice-cold $100 \%$ absolute ethanol. Tubes were stored at $-20^{\circ} \mathrm{C}$ for approximately $1 \mathrm{~h}$. DNA was then recovered by microcentrifugation at $14000 \mathrm{rpm}$ for $15 \mathrm{~min}$, and the ethanol was decanted. The resulting DNA pellet was washed with $200 \mu \mathrm{l}$ of $70 \%$ ethanol, $100 \mathrm{mM}$ sodium acetate solution, and microcentrifuged at $14000 \mathrm{rpm}$ for $3 \mathrm{~min}$. Following decanting, all remaining ethanol was removed using a micropipette. DNA was airdried, resuspended in $100 \mu$ of TE buffer (10 mM Tris $\mathrm{HCl}, \mathrm{pH} 7.6$; and 1 mM EDTA) and stored at $-20^{\circ} \mathrm{C}$. DNA yield was checked on a $1.0 \%$ agarose TBE $(90 \mathrm{mM}$ Tris-borate and $2 \mathrm{mM}$ EDTA; $1 \times$ ) gel, run at $110 \mathrm{~V}$, and stained with GelRed (Biotium). 
PCR was then used to amplify the mitochondrial ND4 gene from all DNA extractions. This gene was selected for analysis following Dudgeon et al. (2009) and Ovenden et al. (2010), who demonstrated the ND4 gene to be the most polymorphic among a range of mtDNA markers (including the control region) in species related to those under study here. PCR reactions were carried out in $50 \mu \mathrm{l}$ volumes containing $1 \mu \mathrm{l}$ of DNA template, $1 \times$ GoTaq Colourless reaction buffer (consisting of $1.5 \mathrm{mM} \mathrm{MgCl}_{2}$ and $200 \mu \mathrm{M}$ deoxynucleoside triphosphates [dNTPs]) (Promega), $0.5 \mu \mathrm{l}$ of RNase $\left(1 \mathrm{mg} \mathrm{ml}^{-1}\right)$, and $0.5 \mu \mathrm{M}$ of each of the primers ND4 (5'CAC CTA TGA CTA CCA AAA GCT CAT GTA GAA GC) (Arèvalo et al. 1994) and H12293-LEU (5' TTG CAC CAA GAG TTT TTG GTT CCT AAG ACC) (Inoue et al. 2001). Amplifications were performed in an Eppendorf ep gradient S Mastercycler, using thermal cycling conditions consisting of an initial denaturation $\left(94^{\circ} \mathrm{C}\right.$ for $\left.3 \mathrm{~min}\right)$ followed by 35 cycles of $94^{\circ} \mathrm{C}$ for $15 \mathrm{~s}, 60^{\circ} \mathrm{C}$ for $30 \mathrm{~s}$ and $72^{\circ} \mathrm{C}$ for $1 \mathrm{~min}$, with a final extension step of $72^{\circ} \mathrm{C}$ for $10 \mathrm{~min}$, and held at $4^{\circ} \mathrm{C}$. PCR products were visualised on a $2.0 \%$ agarose TBE $(1 \times)$ gel, run at $110 \mathrm{~V}$, and stained as above. PCR products were purified prior to sequencing using Exosap-IT (USB Corporation). Sequencing was performed with an Applied Biosystems 3130xl Genetic Analyzer 16-array capillary sequencer (Life Technologies), with sequencing reactions and analyses carried out by the Macquarie University (MQ) DNA Sequencing Facility using Big Dye Terminator reactions and the forward PCR primer only.

\section{Sequence alignment and ID validation}

To assess observer accuracy, species identities were determined following sequence alignment. Sequences were first trimmed and edited by eye. Edited sequences were entered into Biomanager (http://web.archive. org/web/20110721184643/http://biomanager.info/) and aligned using the ClustalW (accurate) algorithm (Thompson et al. 1994). No GenBank ND4 reference sequences were available for C. obscurus or C. plumbeus prior to this study. To validate that the 2 study species had been correctly identified, and to determine the species identity of any misidentified individuals, randomly selected representatives from each separate haplotype determined from the alignment output were amplified for the mitochondrial cytochrome oxidase I (CO1) gene using the primers Fish F1 (5' TCA ACC AAC CAC AAA GAC ATT GGC AC) and Fish R1 (5'TAG ACT TCT GGG TGG CCA AAG AAT CA) (Ward et al. 2005). PCRs were carried out as above, with thermal cycling conditions consisting of an initial denaturation $\left(95^{\circ} \mathrm{C}\right.$ for $\left.5 \mathrm{~min}\right)$, followed by 30 cycles of $95^{\circ} \mathrm{C}$ for $15 \mathrm{~s}, 55^{\circ} \mathrm{C}$ for $30 \mathrm{~s}$ and $72^{\circ} \mathrm{C}$ for $1 \mathrm{~min}$, with a final extension step of $72^{\circ} \mathrm{C}$ for $7 \mathrm{~min}$, and held at $4^{\circ} \mathrm{C}$. PCR products were purified and sequenced following the same protocol outlined above for the ND4 locus. Resultant CO1 sequences were compared with reference sequences in GenBank for species recognition.

\section{Sequence analysis}

To identify and characterise mitochondrial haplotypes, aligned ND4 C. obscurus and C. plumbeus sequences were imported into Arlequin 3.5.1.2 (Excoffier \& Lischer 2010). A sequence representing each haplotype was lodged in GenBank (accession codes KJ004523-KJ004551). The frequency of, and mutational steps between, haplotypes were assessed by generating statistical parsimony haplotype networks in TCS 1.21 using the default settings (Clement et al. 2000). Phylogenetic relationships among haplotypes were inferred using a maximum likelihood phylogram (or phylogenetic tree) based on the Tamura-Nei model (Tamura \& Nei 1993), and generated in MEGA 5 (Tamura et al. 2011) with 1000 bootstrap replicates. The best-fitting model of nucleotide substitution, as offered by MEGA 5, was determined by likelihood ratio tests and calculations of Akaike and Bayesian information criteria performed in jModelTest 2.1.1 (Darriba et al. 2012). To assess the ability of the ND4 region to differentiate between carcharhinids, the phylogram was rooted with a range of morphologically similar species, as well as with 2 sphyrnid species as outgroups. Genetic diversity indices were also obtained with Arlequin using the Tamura-Nei substitution model (Tamura \& Nei 1993), and included polymorphism statistics, number of haplotypes $\left(\mathrm{n}_{\mathrm{H}}\right)$, haplotype diversity $(h)$ and nucleotide diversity $(\pi)$.

\section{Rarefaction exact curve analysis}

To determine whether sample sizes adequately represented population genetic variation, rarefaction exact curves were generated to qualitatively assess the proportion of haplotypic diversity sampled at each location for both C. obscurus and C. plumbeus. The expected number of haplotypes found for a given sample number was calculated using the rarefaction formula of Hurlbert (1971), and executed in the statistical package R (R Development Core Team 2010). 


\section{Genetic diversity and structuring}

For C. plumbeus, a restricted sample distribution permitted the investigation of genetic diversity on a fine scale in NSW waters only. For C. obscurus, however, a suitable sample distribution was available to examine both genetic diversity and population structuring on a regional scale. For this latter species, an analysis of molecular variance (AMOVA; Excoffier et al. 1992) was implemented in Arlequin to test a null hypothesis of panmixia (genetic homogeneity) across Indo-Australian waters. To evaluate the overall extent of genetic subdivision between sampling locations, we employed $2 \mathrm{~F}$-statistic metrics of genetic divergence: $\Phi_{\mathrm{ST}}$ (Excoffier et al. 1992) and $F_{\mathrm{ST}}$ (Wright 1965). While $\Phi_{\mathrm{ST}}$ has been regarded as the superior metric on the basis of its incorporation of a measure of genetic distance between haplotypes, frequencybased $F_{\mathrm{ST}}$ has been proposed as a more appropriate measure of genetic differentiation among locations where migration is theoretically occurring at a faster rate than mutation (Bird et al. 2011). $\Phi_{\mathrm{ST}}$ was calculated via the computing of a distance matrix using the Tamura-Nei model (Tamura \& Nei 1993) for estimation of genetic distance between sequences, while $F_{\text {ST }}$ used haplotype frequencies only. AMOVA partitioned genetic variance among, and within, populations and calculated $\Phi_{\mathrm{ST}}$ and $F_{\mathrm{ST}}$ fixation indices. Genetic differentiation between sample locations was also measured by calculating pairwise $\Phi_{\mathrm{ST}}$ and $F_{\mathrm{ST}}$ estimates. Statistical significance was determined following 10000 permutations of the sequence data and, in the case of pairwise $\Phi_{\mathrm{ST}}$ and $F_{\mathrm{ST}}$, assessed at an initial critical significance level of $\alpha=0.0083$ (adjusted from $\alpha=0.05$ ) following sequential Bonferroni correction for 6 simultaneous comparisons (Holm 1979). The AMOVA structure consisted of 1 group made up of the following 4 putative populations: NSW ( $\mathrm{n}=301)$, NT ( $n=49)$, WA $(n=57)$ and Indonesia $(n=16$; Fig. 1). The analysis outlined above is henceforth referred to as the 'original analysis'.

C. obscurus sample sizes were strongly biased towards NSW, where sample numbers were an order of magnitude greater than at the remaining 3 locations (Fig. 1). We evaluated the influence of this sampling bias on the $F$-statistics of pairwise population comparisons involving NSW via random re-sampling simulations. Ten thousand replicate random sample sets of $n=100, n=50$ and $n=16$ (for comparison with Indonesia only) were selected without replacement from the NSW population, while NT, WA and Indonesian sample sizes were kept unchanged. Population pairwise $\Phi_{\mathrm{ST}}$ and associated p-values were gen- erated for each replicate random sample set in Arlequin using the batch processing function and permutation settings as outlined above. Resultant $\Phi_{\mathrm{ST}}$ and p-value distributions were plotted, and the likelihood of producing a contradictory result to that of the original analysis was calculated as the percentage of $\mathrm{p}$ values either $\leq 0.05$ or $>0.05$, depending on the outcome of the original analysis.

\section{RESULTS}

\section{Observer accuracy off Australia's NSW coast}

The ND4 gene region proved to be an excellent marker for carcharhinid species recognition (Fig. 2), as also shown by Tillett et al. (2012c), hence confirming its suitability for use in the present study.

Genetic validation was possible for a total of 296 sharks visually identified by scientific observers as Carcharhinus obscurus in the NSW OTLF from 2007 to 2010. Of these, 286 were genetically confirmed to be $C$. obscurus, translating to an observer-accuracy estimate of $96.6 \%$ for the identification of this species in the fishery (Table 1). Misidentified individuals $(n=10)$ were all of adult size and represented 6 different carcharhinid species (Table 1).

Genetic validation was possible for a total of 487 sharks visually identified by scientific observers as $C$. plumbeus in this same fishery over the same temporal period. Of these, 484 were genetically confirmed to be $C$. plumbeus, translating to an observer-accuracy estimate of $99.4 \%$ for the identification of this species in the NSW OTLF (Table 1). Misidentifications $(n=3)$ once again were all of adult size and comprised 3 different carcharhinid species (Table 1). Overall observer accuracy was estimated at $98.3 \%$ for the identification of these 2 target species combined.

\section{Genetic diversity and summary statistics}

\section{Carcharhinus obscurus}

An 857 bp mtDNA ND4 sequence was obtained for 423 C. obscurus individuals collected from Australian and Indonesian waters (Fig. 1). A total of 18 haplotypes were defined, characterised by 18 polymorphic sites composed of 15 transitions and 3 transversions (see Table A1 in the Appendix). Phylogenetic analysis placed these haplotypes into 2 shallow clades (Fig. 2). Two haplotypes (DS9 and, to a lesser degree, DS15) dominated the sample set, and were common at all 4 


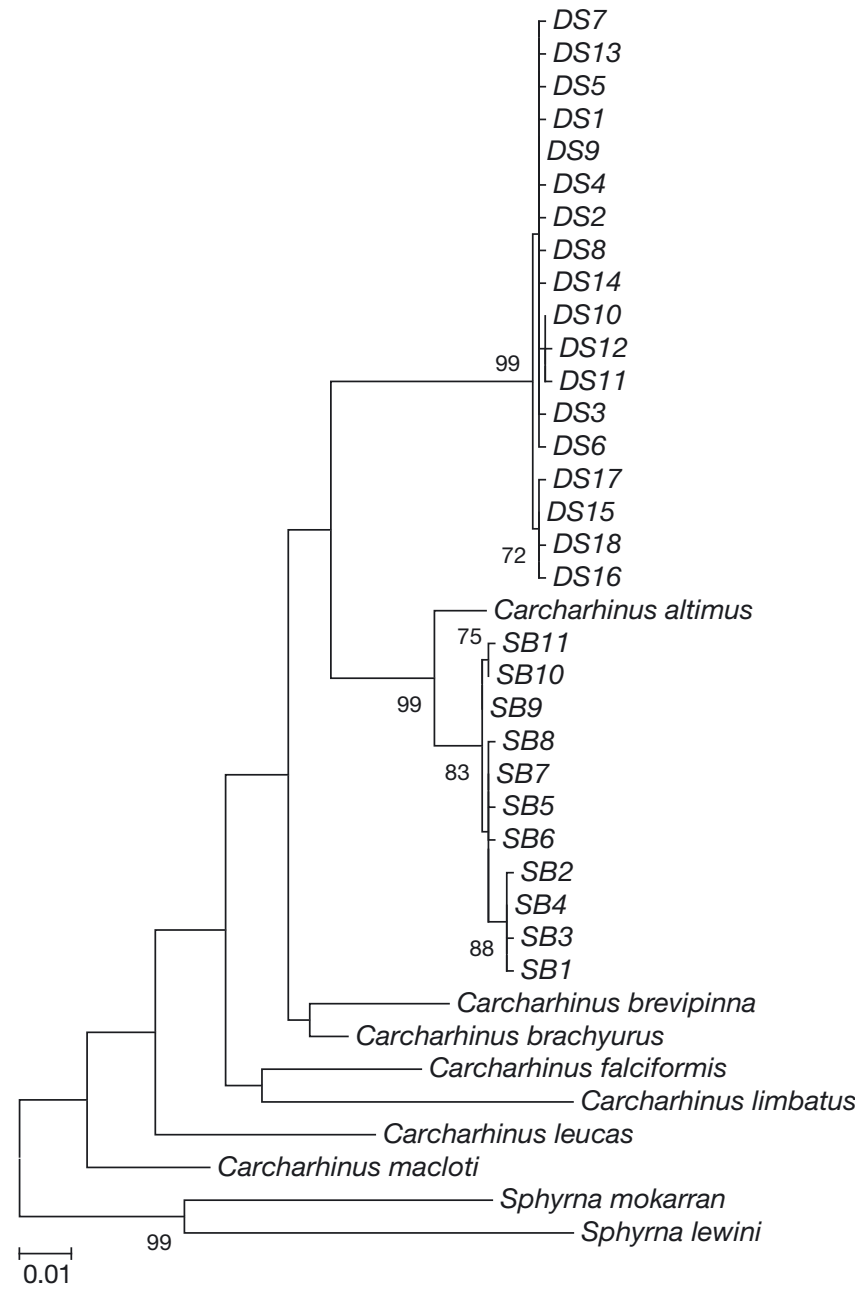

Fig. 2. Inferred phylogenetic maximum likelihood tree for Carcharhinus obscurus (DS1-18) and C. plumbeus (SB1-11) mtDNA ND4 haplotypes from Australian and Indonesian waters. Nodal bootstrap support is displayed where $\geq 70 \%$. Scale represents the proportion of polymorphic sites between haplotypes locations (Table 2a). Overall haplotype (h) and nucleotide $(\pi)$ diversities were moderate and low, respectively ( $h=0.5150, \pi=0.0012$; Table 3 ). Notwithstanding differences in sample size, the greatest number of haplotypes $(n=12)$ was found in NSW waters, of which 5 were unique to the area (Table 3 ). Ten haplotypes were found in WA waters, 3 of which were unique, and 5 haplotypes were found in both NT and Indonesia, each exhibiting 1 unique haplotype. Haplotype and nucleotide diversities ranged across the putative populations; Indonesia displayed the highest diversity values $(h=0.7500, \pi=0.0016)$ and NT the lowest ( $h=0.3520, \pi=0.0008)$. Standard deviation estimates, however, rendered differences in diversity between the locations impossible to discern (Table 3).

\section{Carcharhinus plumbeus}

An 857 bp mtDNA ND4 sequence was obtained for 442 C. plumbeus individuals collected from eastern and northern Australian waters (Fig. 1). A total of 11 haplotypes were defined, characterised by 12 polymorphic sites composed exclusively of transitions (see Table A2 in Appendix 1). Phylogenetic analysis placed these haplotypes into 2 shallow clades (Fig. 2). Two haplotypes (SB4 and, to a far lesser degree, SB7) dominated the sample set (Table 2b). Overall haplotype and nucleotide diversities were low for C. plumbeus, at 0.2814 and 0.0009 , respectively (Table 3 ). No unique haplotypes were found amongst the 2 NT samples, with both being the most common haplotype SB4 (Table 2b). Given the low sample size from NT, this location was henceforth excluded from further analyses, with detailed investigations focusing exclusively on eastern Australian (NSW) waters.
Table 1. Percentage of individuals identified by observers as Carcharhinus obscurus and C. plumbeus for each genetically identified shark species in the New South Wales Ocean Trap and Line Fishery. The number of individuals is given in parentheses; bold print shows percentage of correctly identified $C$. obscurus and C. plumbeus. Total lengths (TL; $\mathrm{Cm}$ ) for misidentified individuals are displayed; na: not applicable

\begin{tabular}{|lcccc|}
\hline $\begin{array}{l}\text { Genetic } \\
\text { identification }\end{array}$ & $\begin{array}{c}\text { Observer } \\
\text { identified as } \\
\text { C. obscurus }\end{array}$ & $\begin{array}{c}\text { TL of mis- } \\
\text { identified } \\
\text { ind. }\end{array}$ & $\begin{array}{c}\text { Observer } \\
\text { identified as } \\
\text { C. plumbeus }\end{array}$ & $\begin{array}{c}\text { TL of mis- } \\
\text { identified } \\
\text { ind. }\end{array}$ \\
\hline C. obscurus & $\mathbf{9 6 . 6 ( 2 8 6 )}$ & na & $0.2(1)$ & 302 \\
C. plumbeus & $0.3(1)$ & 210 & $\mathbf{9 9 . 4}(484)$ & na \\
C. falciformis & $1.0(3)$ & $235,242,256$ & $0.2(1)$ & 214 \\
C. leucas & $0.7(2)$ & 220,293 & 0 & na \\
C. limbatus & $0.7(2)$ & 252,254 & $0.2(1)$ & 208 \\
C. brevipinna & $0.3(1)$ & 276 & 0 & na \\
C. altimus & $0.3(1)$ & 269 & 0 & na \\
Total & 296 & & 487 & \\
\hline
\end{tabular}

\section{Rarefaction exact curves}

Rarefaction exact curves indicated trends towards asymptotic relationships for NSW waters in both Carcharhinus obscurus and C. plumbeus (Fig. 3), suggesting that the majority of the available haplotypic diversities were likely sampled at this location in both species and that more intensive sampling was likely to yield few additional haplotypes. Steep slopes, however, were observed for the remaining 3 C. obscurus sample locations (Fig. 3), indicating that a proportion of 
Table 2. Mitochondrial DNA ND4 haplotype relative frequencies observed from putative populations in Indo-Australian waters for (a) Carcharhinus obscurus and (b) C. plumbeus. NSW: New South Wales; NT: Northern Territory; WA: Western Australia; (-) haplotype not found

\begin{tabular}{|c|c|c|c|c|c|}
\hline \multirow{2}{*}{$\begin{array}{l}\text { (a) } \\
\text { Haplotype }\end{array}$} & \multicolumn{4}{|c|}{ - Relative frequency } & \multirow{2}{*}{$\begin{array}{c}\text { GenBank } \\
\text { accession } \\
\text { code }\end{array}$} \\
\hline & $\begin{array}{c}\text { NSW } \\
(\mathrm{n}=301)\end{array}$ & $\begin{array}{c}\text { NT } \\
(\mathrm{n}=49)\end{array}$ & $\begin{array}{c}\text { WA } \\
(\mathrm{n}=57)\end{array}$ & $\begin{array}{c}\text { Indonesia } \\
(\mathrm{n}=16)\end{array}$ & \\
\hline DS1 & - & - & 0.018 & - & KJ004534 \\
\hline DS2 & - & - & 0.018 & - & KJ004535 \\
\hline DS3 & - & - & 0.053 & - & KJ004536 \\
\hline DS4 & - & - & - & 0.063 & KJ004537 \\
\hline DS5 & - & 0.020 & - & 0.063 & KJ004538 \\
\hline DS6 & - & 0.020 & - & - & KJ004539 \\
\hline DS7 & 0.003 & - & 0.018 & - & KJ004540 \\
\hline DS8 & 0.010 & - & 0.018 & - & KJ004541 \\
\hline DS9 & 0.648 & 0.796 & 0.702 & 0.438 & KJ004542 \\
\hline DS10 & 0.040 & - & 0.053 & 0.188 & KJ004543 \\
\hline DS11 & 0.007 & - & 0.018 & - & KJ004544 \\
\hline DS12 & 0.003 & - & - & - & KJ004545 \\
\hline DS13 & 0.003 & - & - & - & KJ004546 \\
\hline DS14 & 0.020 & - & - & - & KJ004547 \\
\hline DS15 & 0.239 & 0.143 & 0.070 & 0.250 & KJ004548 \\
\hline DS16 & 0.003 & - & - & - & KJ004549 \\
\hline DS17 & 0.013 & 0.020 & 0.035 & - & KJ004550 \\
\hline DS18 & 0.010 & - & - & - & KJ004551 \\
\hline & \multicolumn{2}{|c|}{ Relative frequency } & \multicolumn{2}{|c|}{ GenBank } & \\
\hline Haplotype & $\begin{array}{c}\text { NSW } \\
(\mathrm{n}=440)\end{array}$ & $\begin{array}{c}\text { NT } \\
(n=2)\end{array}$ & $\begin{array}{r}\text { acce } \\
\text { co }\end{array}$ & $\begin{array}{l}\text { ession } \\
\text { ode }\end{array}$ & \\
\hline SB1 & 0.011 & - & KJ00 & 04523 & \\
\hline SB2 & 0.014 & - & KJ00 & 04524 & \\
\hline SB3 & 0.005 & - & KJ00 & 04525 & \\
\hline SB4 & 0.841 & 1.000 & KJ00 & 04526 & \\
\hline SB5 & 0.005 & - & KJ00 & 04527 & \\
\hline SB6 & 0.002 & - & KJ00 & 04528 & \\
\hline SB7 & 0.102 & - & KJ00 & 04529 & \\
\hline SB8 & 0.009 & - & KJ00 & 04530 & \\
\hline SB9 & 0.005 & - & KJ00 & 04531 & \\
\hline SB10 & 0.005 & - & KJ00 & 04532 & \\
\hline SB11 & 0.002 & - & KJ00 & 04533 & \\
\hline
\end{tabular}

the available genetic diversities were unsampled. These analyses suggest that adequate representations of levels of genetic variation in C. obscurus or $C$. plumbeus in Indo-Australian waters are reliant on sample sizes in excess of 100 from any given location.

\section{Carcharhinus obscurus: regional genetic structure}

A haplotype network incorporating the 4 putative populations of C. obscurus demonstrated the presence of 2 shallow clades centred on the 2 most common haplotypes, DS9 and DS15, both of which were shared between all 4 sample locations (Fig. 4). Lowfrequency variants shared between, and unique to,
Table 3. Genetic diversity indices observed in the mitochondrial DNA ND4 region for Carcharhinus obscurus and C. plumbeus sample locations from Australian and Indonesian waters. (Location abbreviations as in Table 2.) Values in parentheses represent standard deviations. $\mathrm{n}$ : sample size; $\mathrm{n}_{\mathrm{H}}$ : number of haplotypes; $\mathrm{n}_{\mathrm{Hq}}$ : number of unique haplotypes; $h$ : haplotype diversity; $\pi$ : nucleotide diversity. na: not applicable

\begin{tabular}{|lccccc|}
\hline Location & $\mathrm{n}$ & $\mathrm{n}_{\mathrm{H}}$ & $\mathrm{n}_{\mathrm{Hq}}$ & $h$ & $\pi$ \\
\hline C. obscurus & & & & & \\
NSW & 301 & 12 & 5 & $0.5224( \pm 0.027)$ & $0.0012( \pm 0.0009)$ \\
NT & 49 & 5 & 1 & $0.3520( \pm 0.080)$ & $0.0008( \pm 0.0007)$ \\
WA & 57 & 10 & 3 & $0.5031( \pm 0.080)$ & $0.0010( \pm 0.0008)$ \\
Indonesia & 16 & 5 & 1 & $0.7500( \pm 0.078)$ & $0.0016( \pm 0.0012)$ \\
Pooled & 423 & 18 & na & $0.5150( \pm 0.025)$ & $0.0012( \pm 0.0009)$ \\
C. plumbeus & & & & & na \\
NSW & 440 & 11 & na & $0.2826( \pm 0.027)$ & $0.0009( \pm 0.0008)$ \\
NT & 2 & 1 & na & na & na \\
Pooled & 442 & 11 & na & $0.2814( \pm 0.027)$ & $0.0009( \pm 0.0008)$ \\
a Diversity indices not available for C. plumbeus from NT; both \\
samples were the same haplotype
\end{tabular}

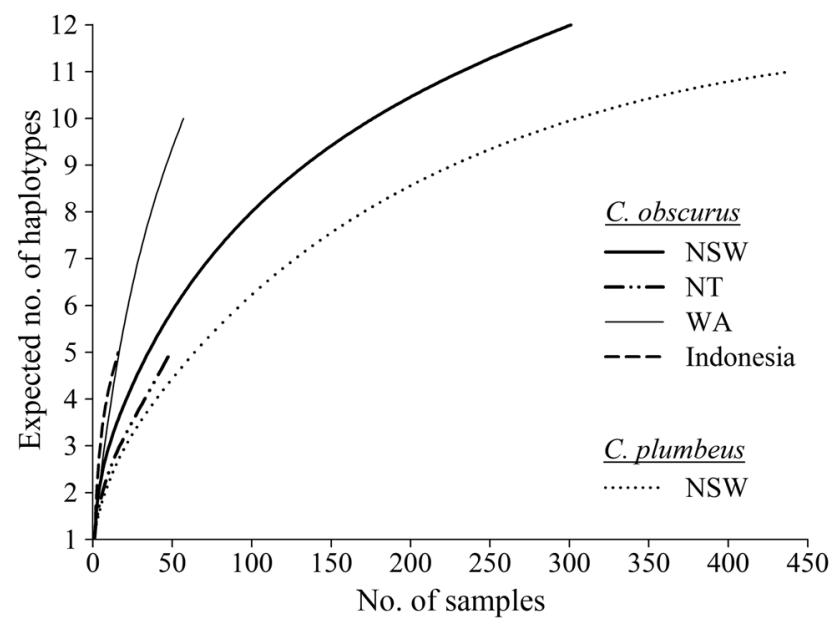

Fig. 3. Rarefaction exact curves for Carcharhinus obscurus and C. plumbeus collection locations in Australian and Indonesian waters. NSW: New South Wales; NT: Northern Territory; WA: Western Australia

locations were also present. Nevertheless, AMOVA fixation indices detected significant levels of differentiation between putative populations for both $F$-statistic metrics $\left(\Phi_{\mathrm{ST}}=0.02462, \mathrm{p}<0.03 ; F_{\mathrm{ST}}=0.02723\right.$, $\mathrm{p}<0.01$; Table 4$)$. We therefore rejected the null hypothesis that $C$. obscurus are panmictic in Indo-Australian waters. Pairwise comparisons revealed weak genetic subdivision between eastern and western Australia, significant after sequential Bonferroni adjustment for $\Phi_{\mathrm{ST}}$ only (NSW versus $\mathrm{WA}_{i} \Phi_{\mathrm{ST}}=$ 0.04437, p $<0.008 ; F_{\mathrm{ST}}=0.02403, \mathrm{p}<0.05$; Table 5). Evidence for weak differentiation between NT and Indonesia $\left(F_{\mathrm{ST}}=0.13925, \mathrm{p}<0.05\right)$ and between WA 
Table 4. AMOVA analyses of spatial genetic variation of mitochondrial DNA ND4 sequences for Carcharhinus obscurus from Australian and Indonesian waters

\begin{tabular}{|lccccc|}
\hline $\begin{array}{l}\text { Source of } \\
\text { variation }\end{array}$ & df & $\begin{array}{c}\text { Test } \\
\text { statistic }\end{array}$ & SS & $\begin{array}{c}\text { Variance } \\
\text { components }\end{array}$ & $\begin{array}{c}\text { Variation } \\
(\%)\end{array}$ \\
\hline Among & 3 & $\Phi_{\mathrm{ST}}$ & 3.875 & 0.01235 & 2.46 \\
populations & & $F_{\mathrm{ST}}$ & 2.149 & 0.00712 & 2.72 \\
Within & 419 & $\Phi_{\mathrm{ST}}$ & 205.056 & 0.48939 & 97.54 \\
populations & & $F_{\mathrm{ST}}$ & 106.517 & 0.25422 & 97.28 \\
$\begin{array}{l}\text { Fixation } \\
\text { indices }\end{array}$ & $\Phi_{\mathrm{ST}}=0.02462 ; \mathrm{p}=0.02143( \pm 0.00099)$ \\
& $F_{\mathrm{ST}}=0.02723 ; \mathrm{p}=0.00999( \pm 0.00069)$ \\
\hline
\end{tabular}

Table 5. Mitochondrial DNA ND4 population pairwise $\Phi_{\mathrm{ST}}$ (below diagonal) and $F_{\mathrm{ST}}$ (above diagonal) estimates of genetic divergence for Carcharhinus obscurus collected from Indo-Australian waters. Bold indicates that the pairwise value is significant after sequential Bonferroni correction (initial $\alpha=0.0083$ ); ${ }^{*}$ denotes values significant at the $\mathrm{p} \leq 0.05$ level. (Location abbreviations as in Table 2)

\begin{tabular}{|lcccc|}
\hline & $\begin{array}{c}\text { NSW } \\
(\mathrm{n}=301)\end{array}$ & $\begin{array}{c}\text { NT } \\
(\mathrm{n}=49)\end{array}$ & $\begin{array}{c}\text { WA } \\
(\mathrm{n}=57)\end{array}$ & $\begin{array}{c}\text { Indonesia } \\
(\mathrm{n}=16)\end{array}$ \\
\hline $\mathrm{NSW}$ & & 0.02208 & $0.02403^{*}$ & 0.03592 \\
$\mathrm{NT}$ & 0.01362 & & 0.00668 & $0.13925^{*}$ \\
WA & $\mathbf{0 . 0 4 4 3 7}$ & 0.00285 & & $0.07440^{*}$ \\
Indonesia & -0.00597 & 0.02476 & 0.03010 & \\
\hline
\end{tabular}

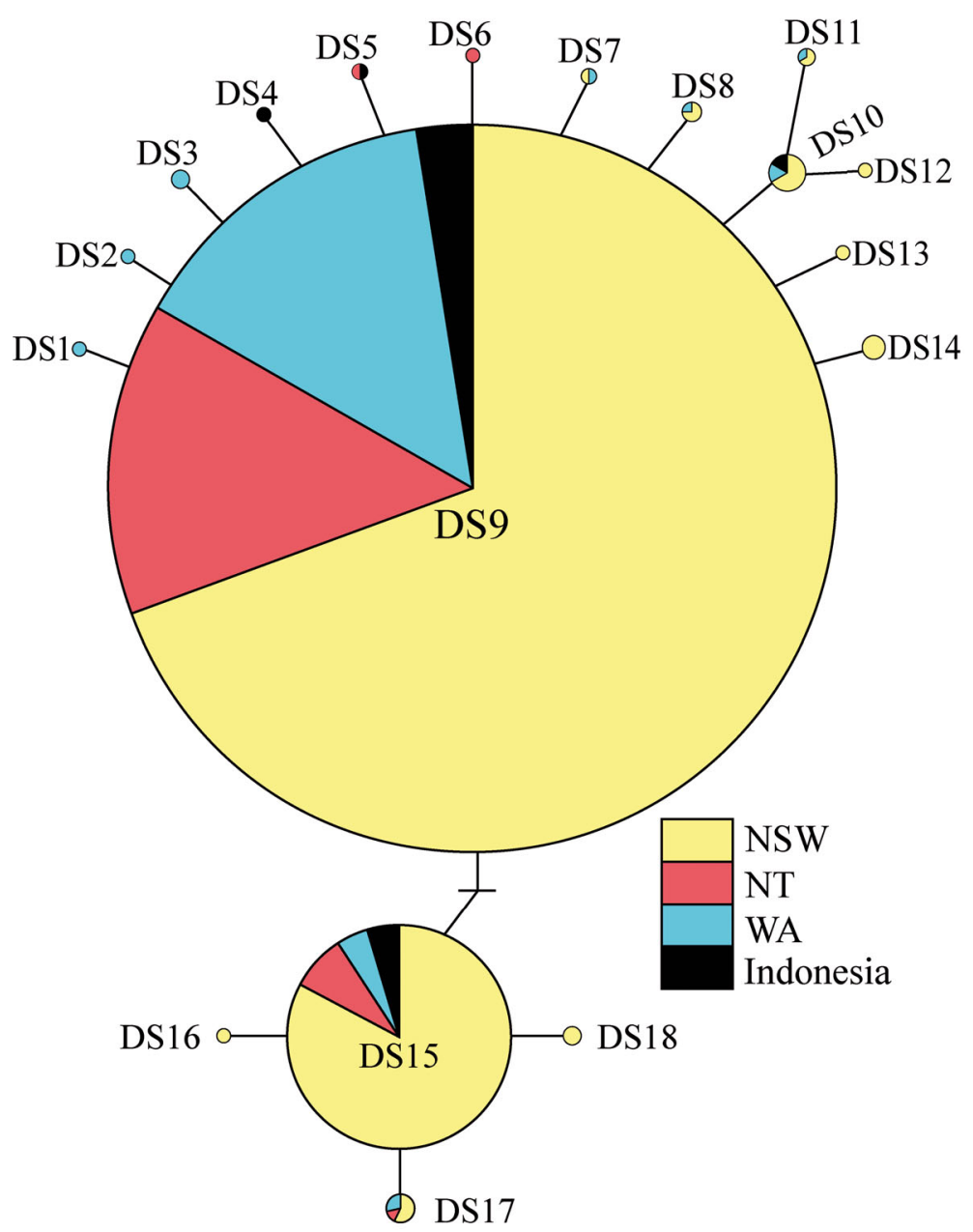

Fig. 4. Mitochondrial DNA ND4 haplotype network for Carcharhinus obscurus $(\mathrm{n}=423)$ from Australian and Indonesian waters. Sizes of circles correspond to the number of individuals displaying each haplotype. Colours indicate the proportion observed from each of the 4 putative populations. (-) mutational step/missing haplotype. NSW: New South Wales; NT: Northern Territory; WA: Western Australia and Indonesia $\left(F_{\mathrm{ST}}=0.07440, \mathrm{p}<0.05\right)$ was also detected based on haplotype frequencies, with neither comparison significant after Bonferroni correction.

Random re-sampling simulations, however, demonstrated an increasing likelihood of finding a non-significant pairwise result between NSW and WA with decreasing NSW sample size (Fig. 5). More specifically, $14.18 \%$ of replicate comparisons where sample size was set to 100 for NSW (and left at 57 for WA) did not provide statistical support for the original analysis, where sample size was 57 for WA and 301 for NSW. This increased to $36.8 \%$ when the NSW sample size was reduced to 50 . In addition, pairwise $\Phi_{\mathrm{ST}}$ distributions displayed stable mean $\Phi_{\mathrm{ST}}$ values (despite increased variation) but increasing mean $\mathrm{p}$-values relative to the output of the original analysis as random NSW sample-set size decreased (Fig. 6). Simulations involving random NSW sample sets of $n=100$ returned pairwise $\Phi_{\mathrm{ST}}$ values normally distributed around a mode (and mean) very near the $\Phi_{\mathrm{ST}}$ produced by the original analysis, and a mean p-value $<0.05$ (Fig. 6a). Simulations involving random NSW sample sets of $\mathrm{n}=$ 50 , despite a more variable and skewed distribution, once again returned a mean $\Phi_{\text {ST }}$ very near that produced by the original analysis, but in contrast returned a non-significant mean p-value $(>0.05$; Fig. 6b). Replicate pairwise comparisons between NSW and NT and Indonesia, in contrast, displayed little change in the likelihood of returning a contradictory 
result to the original analysis as random NSW sample size was altered (Fig. 5).

\section{Species comparison off the NSW coast}

There was a marked similarity in mtDNA features between $C$. obscurus and $C$. plumbeus samples collected from NSW waters. Large sample sets revealed

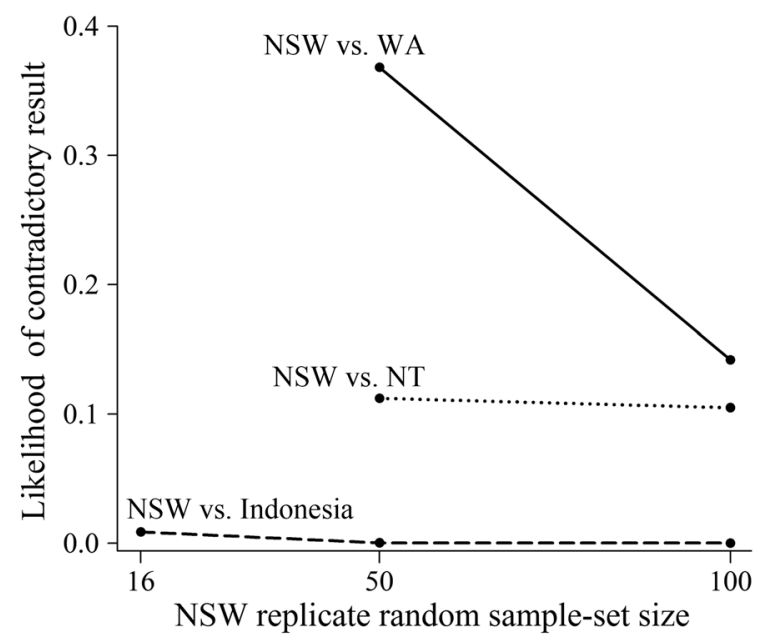

Fig. 5. Likelihood of generating a contradictory pairwise result to that of the original analysis given 10000 replicate random re-samples of the New South Wales (NSW) Carcharhinus obscurus population at varying sample sizes. NT: Northern Territory; WA: Western Australia similar numbers of haplotypes for C. obscurus $\left(\mathrm{n}_{\mathrm{H}}=\right.$ 12, $\mathrm{n}=301)$ and C. plumbeus $\left(\mathrm{n}_{\mathrm{H}}=11, \mathrm{n}=440\right)$ (Table 3). Comparative haplotype networks revealed strikingly similar topologies for the 2 species, with both networks being shallow and suggestive of the presence of 2 distinct, yet closely related, clades separated by 1 to 2 mutation steps (Fig. 7). A difference between the 2 species, however, was observed in their diversity indices, where $C$. obscurus exhibited moderate $(h=0.5224)$, and $C$. plumbeus low $(h=$ 0.2826), genetic diversity (Table 3 ).

\section{DISCUSSION}

\section{Observer accuracy in a NSW shark fishery}

Genetic validation revealed high observer accuracy in the identification of Carcharhinus obscurus and $C$. plumbeus in the NSW OTLF. This was not unexpected given the morphological distinctions coupled with a large modal size-at-capture within the fishery; the vast majority of the shark catch in the NSW OTLF is landed as mature, adult individuals (Macbeth et al. 2009). While morphologically similar to one another, and to a range of other species, at smaller sizes, C. obscurus and C. plumbeus are characterised by diagnostic traits that become increasingly discernible as the individuals grow larger (Last \& Stevens 2009).
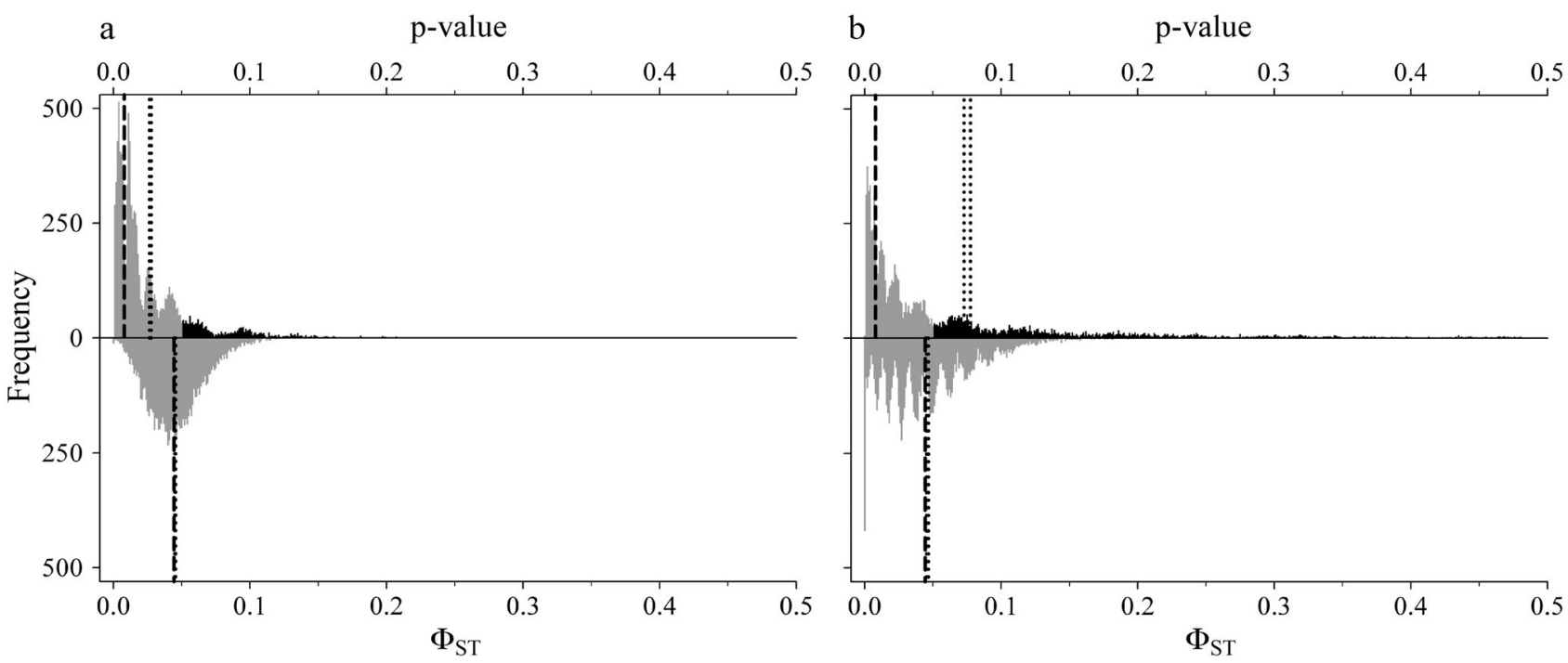

Fig. 6. New South Wales versus Western Australia pairwise $\Phi_{\mathrm{ST}}$ (see 'Materials and methods: Genetic diversity and structuring' for details) and p-value distributions following 10000 replicate random re-samples of the NSW Carcharhinus obscurus population at (a) $n=100$ and (b) $n=50$. Grey and black zones on simulated $p$-value distributions represent $p \leq 0.05$ and $p>0.05$, respectively. Dotted lines denote upper and lower $95 \%$ confidence intervals around simulated means (upper and lower intervals are difficult to discern due to their proximity). Dashed lines indicate the pairwise $\Phi_{\mathrm{ST}}$ and $\mathrm{p}$-value generated by the original analysis 

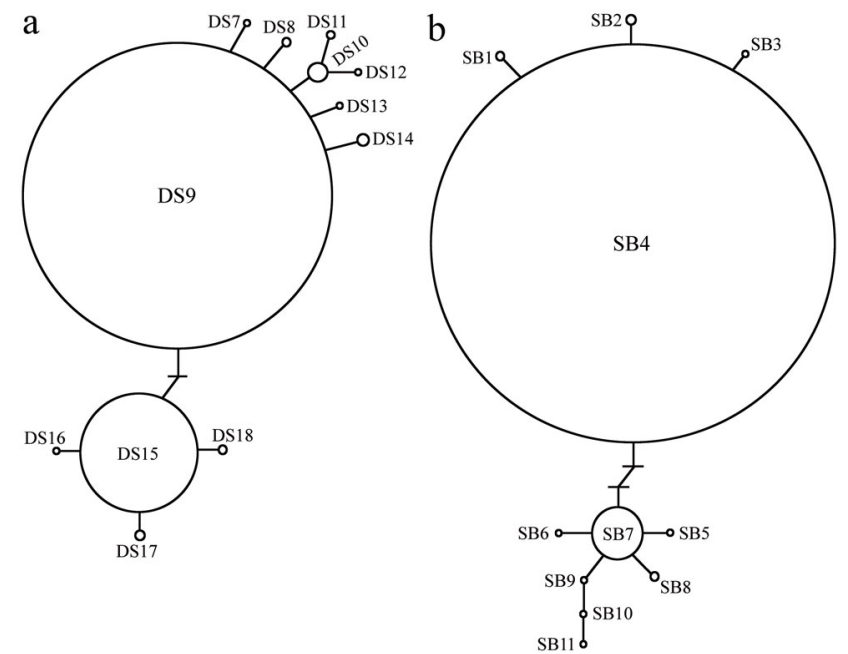

Fig. 7. Comparative ND4 haplotype networks for (a) Carcharhinus obscurus $(\mathrm{n}=301)$ and $(\mathrm{b}) C$. plumbeus $(\mathrm{n}=440)$ in NSW waters. Sizes of circles correspond to the relative frequency of each haplotype. (-), mutational steps/missing haplotypes

Our estimates of observer accuracy were markedly higher than those reported from the NT ONLF by Tillett et al. (2012c), who estimated overall observer accuracy at $80 \%$ compared with $98.3 \%$ in the present study. Also, species-specific identification accuracy ranged from 70 to $92.7 \%$ in northern Australia (Tillett et al. 2012c), compared with 96.6 to $99.4 \%$ off the east coast as presented here. Lower observer accuracy in the NT ONLF can be attributed to the targeting of morphologically similar species (e.g. Australian blacktip C. tilstoni and C. limbatus; C. leucas and C. amboinensis) at predominantly neonate and small juvenile life stages. The NSW OTLF, therefore, is less vulnerable to observer-based catch-data inaccuracies than the northern Australian shark fishery.

\section{Regional gene flow in Carcharhinus obscurus}

This study represents a re-assessment of genetic structure in C. obscurus from Indo-Australian waters, following on from Ovenden et al. (2009). Using a different mtDNA marker, higher sample numbers and the addition of northern Australian samples, we detected weak genetic subdivision between eastern and western Australia. We observed genetic homogeneity, however, between northern Australia and both eastern and western Australia. In considering the Indonesian population, the application of $2 \mathrm{~F}$-statistic metrics $\left(\Phi_{\mathrm{ST}}\right.$ and $\left.F_{\mathrm{ST}}\right)$ produced contrasting results, with some evidence for differentiation between Indonesia and Australia based on haplotype frequen- cies. Discrepancies between these 2 metrics can arise due to their differing methods of calculation, and typically occur when genetic subdivision is at the margins of statistical significance (Broderick et al. 2011).

Our finding of unencumbered gene flow between northern Australia and more southern regions (NSW and WA) was not surprising from a point of view of dispersal potential. C. obscurus attains a large size (Last \& Stevens 2009) and is suspected of undergoing long-range temperature-driven migrations on a seasonal basis, with tagging studies revealing an ability to travel considerable distances (Hussey et al. 2009, Rogers et al. 2013). Our findings of genetic subdivision between eastern and western Australia, however, challenge those of Ovenden et al. (2009) and also Benavides et al. (2011b), who failed to detect genetic differentiation between these same 2 locations using control region sequence data. We also provide evidence for and against the findings of Ovenden et al. (2009) relating to genetic subdivision between Australia and Indonesia. While these disparities may be accounted for by the examining of different genetic markers, the conclusions drawn by the above-mentioned authors were suitably circumspect given the generally low sample numbers upon which their comparisons were based.

Despite the comparatively robust sample numbers used in the present study, we, too, have reason to be circumspect in our findings. Random-resampling simulations offered some evidence that our detection of significant genetic differentiation between NSW and WA was driven, in part, by the strong bias in sample sizes between the 2 locations. Replicate pairwise comparisons indicated an increasing likelihood of finding a non-significant result between the 2 regions as the NSW sample size was decreased towards a more balanced analysis. These simulations either highlight the weak nature of genetic subdivision between Australia's east and west coasts or draw its actual existence into question. Conversely, replicate pairwise comparisons between NSW and NT and Indonesia appeared to be unaffected by a balancing of the NSW sample size, suggestive that the outcomes of the original analysis were robust to biased sample sizes in these instances.

Rarefaction analysis emphasised an additional limitation of our study. NSW was demonstrated as the only location at which an adequate proportion of the available genetic variability was likely sampled, with much of the available diversity appearing to have remained unsampled from NT and Indonesia, and possibly also WA. The rarefaction exact curves suggested that sample sizes in excess of 100 (and even 
up to 150) may be required to accurately represent levels of genetic diversity, and hence to confidently discern haplotype relative frequencies at any given location. It is important to consider, however, that these particular results pertain specifically to the ND4 region and should not be applied to other mitochondrial genes. We would anticipate rarefaction curve trajectory, and therefore optimum sample size estimates, to be heavily reliant on the degree of polymorphism of the mtDNA region employed. Nevertheless, these findings serve as a cautionary note for studies investigating genetic structure over fine and regional spatial scales, where signals of genetic differentiation are unlikely to be strong, and reiterate that conclusions based on small sample sizes should be treated with considerable caution. For this reason, and given the contradicting metric results coupled with our inability to confirm that the samples were actually collected from Indonesian waters, we have henceforth placed little emphasis on results involving the Indonesian location.

Notwithstanding the above-mentioned limitations, evidence for regionally restricted gene flow between eastern and western regions of Australia, as presented in this study for C. obscurus, is consistent with mtDNA research on a range of other shark species representing a broad spectrum of different ecologies and life histories: scalloped hammerhead Sphyrna lewini (Duncan et al. 2006), grey nurse Carcharias taurus (Ahonen et al. 2009), C. plumbeus (Portnoy et al. 2010), pigeye Carcharhinus amboinensis (Tillett et al. 2012a) and great white Carcharodon carcharias (Blower et al. 2012). On comparable geographic scales, genetic subdivision was detected in bull Carcharhinus leucas and common blacktip Carcharhinus limbatus sharks between Gulf of Mexico and north-western Atlantic waters (Keeney et al. 2005, Karl et al. 2011).

Regional and fine-scale genetic subdivision in sharks based on mtDNA is often attributed to reproductive philopatry, a sex-biased behavioural trait widely documented in this taxon (Hueter et al. 2005, Portnoy \& Heist 2012). Discerning reproductive philopatry in a justifiable manner, however, requires a stringent experimental design (Keeney et al. 2005, Dudgeon et al. 2012), which the present study lacked; tissue collection was both spatially and temporally opportunistic, with the exception of WA, where small individuals were sampled over consecutive days. While it is possible that our finding of regional subdivision reflects signs of philopatry, this study is unable to provide an informative test of this hypothesis.

Alternatively, the shallow divergence observed between eastern and western Australian regions may have resulted from repeated periods of isolation associated with the rise and fall of the Torres Strait land-bridge during the Pleistocene epoch, as is hypothesised for Carcharhinus amboinensis by Tillett et al. (2012a). However, unlike C. obscurus, C. amboinensis exhibits a distribution restricted to northern areas in Australian waters (Last \& Stevens 2009). Given the former species' Australia-wide distribution, genetic divergence between eastern and western regions based on this historic, northern physical boundary is difficult to reconcile for C. obscurus, and assumes restricted gene flow across southern Australia, which we can neither refute nor support. Furthermore, under this hypothesis, one would expect similar levels of divergence between NSW and NT, which we did not observe.

\section{Species comparison in NSW waters}

C. obscurus and C. plumbeus exhibited strong similarities in their patterns of genetic diversity in NSW waters. Rarefaction curves from this region suggested that our sample sets had likely captured the majority of the respective genetic diversities available in both species, and hence were accurate representations of each species' genetic structure in the area. The haplotype-network topologies for both species, resolved thus through highly robust sample numbers, were very similar, suggestive that $C$. obscurus and C. plumbeus populations have experienced related evolutionary histories off Australia's east coast. In light of this, given our finding of weak genetic differentiation between the east and west coast in C. obscurus, Portnoy et al.'s (2010) similar result for $C$. plumbeus is perhaps not unexpected. These similarities suggest that $C$. obscurus may, to some degree, be a suitable proxy for patterns of gene flow in C. plumbeus around Australia, excluding southern waters where the latter species is not found.

However, while comparable levels of diversity were found off the east coast based on haplotype numbers, diversity indices indicated low haplotypic diversity in C. plumbeus compared with moderate haplotypic diversity in C. obscurus. This low apparent diversity in C. plumbeus in NSW waters may be accounted for by the exclusive sampling of the species' southern-most distribution limit (Last \& Stevens 2009). Extreme and/or unstable environmental conditions are associated with distribution boundaries, and have been hypothesised to result in low population density and increased genetic drift and inbreeding in peripheral populations (e.g. Arnaud-Haond et 
al. 2006, Lind et al. 2007). If this is indeed the case, one would anticipate the sampling of core Australian populations to reveal increased genetic diversity in C. plumbeus. Given also that this study is focused primarily on impacted populations, it is equally important to consider the potential impact of past anthropogenic pressure on the current observed diversities of both commercially targeted species.

\section{Management implications and further work}

Notwithstanding the limitations discussed earlier, our results tentatively support restricted gene flow in C. obscurus between eastern and western Australia. This suggests the allocation of 2 management units for C. obscurus in Australian waters: eastern and western regions. Under this scenario, stock recovery from a population collapse in the east would rely on reproduction by surviving local individuals and replenishment by immigrants from northern Australia. While the apparent genetic homogeneity involving northern Australia renders the most suitable boundary between these 2 management units uncertain, our results nevertheless support a more integrated approach to management between adjacent Australian states in this species.

The closely related genetic structures observed here in C. obscurus and C. plumbeus in NSW waters, resulting presumably from similar evolutionary histories, raise important implications for the management and conservation of these species. Given that both species appear to have responded similarly to evolutionary influences over time, and given also that both exhibit related biological traits in Australian waters (Simpfendorfer et al. 2002, McAuley et al. 2006, 2007b, Geraghty et al. 2013), it is likely that contemporary environmental and/or anthropogenic pressures will impact the 2 species' populations in a similar manner. Of concern, therefore, is that the majority of both species' genetic diversities in NSW waters is present as low-frequency haplotypes, suggestive of a vulnerability to rapid loss of genetic diversity under intense fishing pressure in the region.

High observer accuracy in the NSW OTLF, however, augurs well for the management of these species and the fishery. Scientifically sound catchcomposition information is a valuable means of recognising fishing-induced ecosystem consequences such as species-specific shifts in abundance, size at capture and/or catch per unit effort (Burgess et al. 2005, Field et al. 2009). The maintenance of such high observer accuracy, however, is somewhat dependent on the fishery maintaining its focus on the more easily identified adults; identification success rate would presumably drop should effort shift to juveniles.

The use of only one mitochondrial marker limited the resolution of the present study, as did the exclusive use of mitochondrial sequence data. We were unable, therefore, to test a null hypothesis that gene flow between the putative populations is equal between males and females. Conflicting genetic structures between mitochondrial and bi-parentally inherited nuclear data (or mito-nuclear discordance) is a widely identified phenomenon in sharks (Portnoy \& Heist 2012). Researchers have typically hypothesised male-biased dispersal (e.g. Pardini et al. 2001, Daly-Engel et al. 2012), also in C. plumbeus between eastern and western Australia (Portnoy et al. 2010), which implies persistent male dispersal despite constrained female gene flow. Patterns of male-mediated gene flow, therefore, can have significant implications with respect to interpretations of genetic subdivision and, in turn, the allocation of appropriate management units (Toews \& Brelsford 2012).

Southern Australian waters were unsampled in this study, highlighting a lack of knowledge regarding gene flow in this region. A recent satellite-tagging study by Rogers et al. (2013) demonstrated the mixing of $C$. obscurus between southern and south-western Australian waters, but not between southern and eastern waters. Their findings, however, were based on data from only 3 individuals tagged in the same location. Given, therefore, that definitive information pertaining to movement (or lack of) between eastern and western Australia is not currently available, genetic sampling of southern waters would greatly improve interpretations of the current data.

With the shortcomings of this study in mind, we recommend this work not be viewed as a definitive template for management policy but rather as a foundation for future studies. We strongly encourage further work aimed at achieving greater genetic structure resolution for $C$. obscurus and $C$. plumbeus in Australian and neighbouring waters via more extensive sampling and the use of more and varied genetic markers. We also urge evaluations of connectivity in these species around Australia, particularly between the east and west coasts. For C. obscurus, we suggest a focus on southern Australian waters. More robust assessments of contemporary gene flow, as well as physical tagging and tracking, would greatly assist the effective management of these species in IndoAustralian waters through the appropriate allocation of management units. 
Acknowledgements. The authors humbly thank the NSW and NT commercial fishers, as well as the scientific observers from the NSW Department of Primary Industries (NSW DPI) and the NT Department of Primary Industry and Fisheries. We appreciate the financial support provided by the Northern Rivers Catchment Management Authority (NRCMA), the Australian Centre for International Agricultural Research, NSW DPI, Macquarie University (MQ), the Queensland Government and an Australian Postgraduate Award scholarship awarded to P.T.G. V. Peddemors of NSW DPI, R. McAuley and J. Chidlow from the Western Australian Department of Fisheries, as well as W. White of the Commonwealth Scientific and Industrial Research Organisation and all members of the Indo-Oz team, are sincerely thanked for their contributions of additional samples. So, too, are J. Stewart and three anonymous reviewers for their useful and constructive comments on the analyses and text. We are also most grateful for the support, assistance and advice generously provided by E. Morgan, C. and A. Geraghty, R. Street, as well as M. Holley, D. Nipperess, L. Vandine, P. Worden, P. Duckett, W. Godinho, J. Boomer and A. Stow of $M Q$.

\section{LITERATURE CITED}

Ahonen H, Harcourt RG, Stow AJ (2009) Nuclear and mitochondrial DNA reveals isolation of imperilled grey nurse shark populations (Carcharias taurus). Mol Ecol 18: 4409-4421

Amorim AF, Arfelli CA, Fagundes L (1998) Pelagic elasmobranchs caught by longliners off southern Brazil during 1974-97: an overview. Mar Freshw Res 49:621-632

Arèvalo E, Davis SK, Sites JWJ (1994) Mitochondrial DNA sequence divergence and phylogenetic relationships among eight chromosome races of the Sceloporus grammicus complex (Phrynosomatidae) in central Mexico. Syst Biol 43:387-418

Arnaud-Haond S, Teixeira S, Massa SI, Billot C and others (2006) Genetic structure at range edge: low diversity and high inbreeding in Southeast Asian mangrove (Avicennia marina) populations. Mol Ecol 15:3515-3525

> Baremore IE, Hale LF (2012) Reproduction of the sandbar shark in the western North Atlantic Ocean and Gulf of Mexico. Mar Coast Fish Dynam Manag Ecosys Sci 4: 560-572

> Barker MJ, Schluessel V (2005) Managing global shark fisheries: suggestions for prioritizing management strategies. Aquat Conserv 15:325-347

Baum JK, Blanchard W (2010) Inferring shark population trends from generalized linear mixed models of pelagic longline catch and effort data. Fish Res 102:229-239

Baum JK, Myers RA, Kehler DG, Worm B, Harley SJ, Doherty PA (2003) Collapse and conservation of shark populations in the northwest Atlantic. Science 299:389-392

> Benavides MT, Feldheim KA, Duffy CA, Wintner S and others (2011a) Phylogeography of the copper shark (Carcharhinus brachyurus) in the southern hemisphere: implications for the conservation of a coastal apex predator. Mar Freshw Res 62:861-869

> Benavides MT, Horn RL, Feldheim KA, Shivji MS and others (2011b) Global phylogeography of the dusky shark Carcharhinus obscurus: implications for fisheries management and monitoring the shark fin trade. Endang Species Res 14:13-22
Bird CE, Karl SA, Smouse PE, Toonen RJ (2011) Detecting and measuring genetic differentiation. In: Koenemann S, Held C, Schubart CD (eds) Phylogeography and population genetics in Crustacea, Crustacean Issues 19. CRC Press, Boca Raton, FL, p 31-55

Blower DC, Pandolfi JM, Bruce BD, Gomez-Cabrera MdC, Ovenden JR (2012) Population genetics of Australian white sharks reveals fine-scale spatial structure, transoceanic dispersal events and low effective population sizes. Mar Ecol Prog Ser 455:229-244

Broderick D, Ovenden JR, Buckworth RC, Newman SJ, Lester RJG, Welch DJ (2011) Genetic population structure of grey mackerel Scomberomorus semifasciatus in northern Australia. J Fish Biol 79:633-661

> Burgess GH, Beerkircher LR, Cailliet GM, Carlson JK and others (2005) Is the collapse of shark populations in the northwest Atlantic Ocean and Gulf of Mexico real? Fisheries 30:19-26

Castillo-Géniz JL, Márquez-Farias JF, Rodriguez de la Cruz MC, Cortés E, Cid del Prado A (1998) The Mexican artisanal shark fishery in the Gulf of Mexico: towards a regulated fishery. Mar Freshw Res 49:611-620

> Clarke SC, Magnussen JE, Abercrombie DL, McAllister MK, Shivji MS (2006) Identification of shark species composition and proportion in the Hong Kong shark fin market based on molecular genetics and trade records. Conserv Biol 20:201-211

> Clement M, Posada D, Crandall KA (2000) TCS: a computer program to estimate gene genealogies. Mol Ecol 9: 1657-1659

Cortés E (2000) Life history patterns and correlations in sharks. Rev Fish Sci 8:299-344

Cortés E, Brooks E, Apostolaki P, Brown CA (2006) Stock assessment of the dusky shark in the U.S. Atlantic and Gulf of Mexico. Panama City Laboratory Contribution 06-05, US Department of Commerce

> Daly-Engel TS, Seraphin KD, Holland KN, Coffey JP, Nance HA, Toonen RJ, Bowen BW (2012) Global phylogeography with mixed-marker analysis reveals male-mediated dispersal in the endangered scalloped hammerhead shark (Sphyrna lewini). PLoS ONE 7:e29986

> Darriba D, Taboada GL, Doallo R, Posada D (2012) jModelTest 2: more models, new heuristics and parallel computing. Nat Methods 9:772

> Dudgeon CL, Broderick D, Ovenden JR (2009) IUCN classification zones concord with, but underestimate, the population genetic structure of the zebra shark Stegostoma fasciatum in the Indo-West Pacific. Mol Ecol 18:248-261

Dudgeon CL, Blower DC, Broderick D, Giles JL and others (2012) A review of the application of molecular genetics for fisheries management and conservation of sharks and rays. J Fish Biol 80:1789-1843

> Dudley SFJ, Cliff G, Zungu MP, Smale MJ (2005) Sharks caught in the protective gill nets off KwaZulu-Natal, South Africa. The dusky shark Carcharhinus obscurus (Lesueur 1818). Afr J Mar Sci 27:107-127

Duncan KM, Martin AP, Bowen BW, De Couet HG (2006) Global phylogeography of the scalloped hammerhead shark (Sphyrna lewini). Mol Ecol 15:2239-2251

> Excoffier L, Lischer HEL (2010) Arlequin suite Ver 3.5: a new series of programs to perform population genetics analyses under Linux and Windows. Mol Ecol Resour 10: $564-567$

> Excoffier L, Smouse PE, Quattro JM (1992) Analysis of molecular variance inferred from metric distances 
among DNA haplotypes: application to human mitochondrial DNA restriction data. Genetics 131:479-491

> Ferretti F, Myers RA, Serena F, Lotze HK (2008) Loss of large predatory sharks from the Mediterranean Sea. Conserv Biol 22:952-964

Ferretti F, Worm B, Britten GL, Heithaus MR, Lotze HK (2010) Patterns and ecosystem consequences of shark declines in the ocean. Ecol Lett 13:1055-1071

Field IC, Meekan MG, Buckworth RC, Bradshaw CJA (2009) Susceptibility of sharks, rays and chimeras to global extinction. Adv Mar Biol 56:275-363

Geraghty PT, Macbeth WG, Harry AV, Bell JE, Yerman MN, Williamson JE (2013) Age and growth parameters for three heavily exploited shark species off temperate eastern Australia. ICES J Mar Sci, doi:10.1093/icesjms/fst164

Hazlitt SL, Goldizen AW, Eldridge MDB (2006) Significant patterns of population genetic structure and limited gene flow in a threatened macropodid marsupial despite continuous habitat in southeast Queensland, Australia. Conserv Genet 7:675-689

Holm S (1979) A simple sequentially rejective multiple test procedure. Scand J Stat 6:65-70

Hueter RE, Heupel MR, Heist EJ, Keeney DB (2005) Evidence of philopatry in sharks and implications for the management of shark fisheries. J Northwest Atl Fish Sci 35:239-247

> Hurlbert SH (1971) The nonconcept of species diversity: a critique and alternative parameters. Ecology 52:577-586

Hussey NE, McCarthy ID, Dudley SFJ, Mann BQ (2009) Nursery grounds, movement patterns and growth rates of dusky sharks, Carcharhinus obscurus: a long-term tag and release study in South African waters. Mar Freshw Res 60:571-583

Inoue JG, Miya M, Tsukamoto K, Nishida M (2001) A mitogenomic perspective on the basal teleostean phylogeny: resolving higher level relationships with longer DNA sequences. Mol Phylogenet Evol 20:275-285

Karl SA, Castro ALF, Lopez JA, Charvet P, Burgess GH (2011) Phylogeography and conservation of the bull shark (Carcharhinus leucas) inferred from mitochondrial and microsatellite DNA. Conserv Genet 12:371-382

Keeney DB, Heist EJ (2006) Worldwide phylogeography of the blacktip shark (Carcharhinus limbatus) inferred from mitochondrial DNA reveals isolation of western Atlantic populations coupled with recent Pacific dispersal. Mol Ecol 15:3669-3679

Keeney DB, Heupel M, Hueter RE, Heist EJ (2003) Genetic heterogeneity among blacktip shark, Carcharhinus limbatus, continental nurseries along the U.S. Atlantic and Gulf of Mexico. Mar Biol 143:1039-1046

> Keeney DB, Heupel MR, Hueter RE, Heist EJ (2005) Microsatellite and mitochondrial DNA analyses of the genetic structure of blacktip shark (Carcharhinus limbatus) nurseries in the northwestern Atlantic, Gulf of Mexico, and Caribbean Sea. Mol Ecol 14:1911-1923

Last PR, Stevens JD (2009) Sharks and rays of Australia, 2nd edn. CSIRO Publishing, Melbourne

> Lind CE, Evans BS, Taylor JJU, Jerry DR (2007) Population genetics of a marine bivalve, Pinctada maxima, throughout the Indo-Australian Archipelago shows differentiation and decreased diversity at range limits. Mol Ecol 16: 5193-5203

Macbeth WG, Geraghty PT, Peddemors VM, Gray CA (2009) Observer-based study of targeted commercial fishing for large sharks in waters off northern New South
Wales. Fisheries Final Report Series No. 114, Industry \& Investment NSW, Sydney

McAuley RB, Simpfendorfer CA, Hyndes GA, Allison RR, Chidlow JA, Newman SJ, Lenanton RCJ (2006) Validated age and growth of the sandbar shark, Carcharhinus plumbeus (Nardo 1827) in the waters off Western Australia. Environ Biol Fishes 77:385-400

> McAuley RB, Simpfendorfer CA, Hall NG (2007a) A method for evaluating the impacts of fishing mortality and stochastic influences on the demography of two long-lived shark stocks. ICES J Mar Sci 64:1710-1722

- McAuley RB, Simpfendorfer CA, Hyndes GA, Lenanton RCJ (2007b) Distribution and reproductive biology of the sandbar shark, Carcharhinus plumbeus (Nardo), in Western Australian waters. Mar Freshw Res 58:116-126

McVean AR, Walker RCJ, Fanning E (2006) The traditional shark fisheries of southwest Madagascar: a study in the Toliara region. Fish Res 82:280-289

Morgan A, Cooper P, Curtis T, Burgess G (2009) Overview of the U.S. East Coast bottom longline shark fishery, 1994-2003. Mar Fish Rev 71:23-38

Musick JA, Grubbs RD, Baum J, Cortés E (2009a) Carcharhinus obscurus. In: IUCN 2012. IUCN Red List of Threatened Species. Version 2012.2. www.iucnredlist. org/details/3852/0

Musick JA, Stevens JD, Baum JK, Bradai M and others (2009b). Carcharhinus plumbeus. In: IUCN 2012. IUCN Red List of Threatened Species. Version 2012.2. www. iucnredlist.org/details/3853/0

> Myers RA, Baum JK, Shepherd TD, Powers SP, Peterson CH (2007) Cascading effects of the loss of apex predatory sharks from a coastal ocean. Science 315:1846-1850

> Ovenden JR, Kashiwagi T, Broderick D, Giles J, Salini J (2009) The extent of population genetic subdivision differs among four co-distributed shark species in the IndoAustralian archipelago. BMC Evol Biol 9:40

> Ovenden JR, Morgan JAT, Kashiwagi T, Broderick D, Salini J (2010) Towards better management of Australia's shark fishery: genetic analyses reveal unexpected ratios of cryptic blacktip species Carcharhinus tilstoni and C. limbatus. Mar Freshw Res 61:253-262

> Pardini AT, Jones CS, Noble LR, Kreiser B and others (2001) Sex-biased dispersal of great white sharks. Nature 412 : 139-140

> Portnoy DS, Heist EJ (2012) Molecular markers: progress and prospects for understanding reproductive ecology in elasmobranchs. J Fish Biol 80:1120-1140

> Portnoy DS, McDowell JR, Heist EJ, Musick JA, Graves JE (2010) World phylogeography and male-mediated gene flow in the sandbar shark, Carcharhinus plumbeus. Mol Ecol 19:1994-2010

R Development Core Team (2010) R: a language and environment for statistical computing. www.R-project.org

Reid DD, Robbins WD, Peddemors VM (2011) Decadal trends in shark catches and effort from the New South Wales, Australia, Shark Meshing Program 1950-2010. Mar Freshw Res 62:676-693

Riginos C, Nachman MW (2001) Population subdivision in marine environments: the contributions of biogeography, geographical distance and discontinuous habitat to genetic differentiation in a blennoid fish, Axoclinus nigricaudus. Mol Ecol 10:1439-1453

Rogers PJ, Huveneers C, Goldsworthy SD, Mitchell JG, Seuront L (2013) Broad-scale movements and pelagic habitat of the dusky shark Carcharhinus obscurus off southern 
Australia determined using pop-up satellite archival tags. Fish Oceanogr 22:102-112

Romine JG, Musick JA, Burgess GH (2009) Demographic analyses of the dusky shark, Carcharhinus obscurus, in the northwest Atlantic incorporating hooking mortality estimates and revised reproductive parameters. Environ Biol Fishes 84:277-289

Simpfendorfer C, Donohue K (1998) Keeping the fish in 'fish and chips': research and management of the Western Australian shark fishery. Mar Freshw Res 49:593-600

Simpfendorfer CA, McAuley RB, Chidlow J, Unsworth P (2002) Validated age and growth of the dusky shark, Carcharhinus obscurus, from Western Australian waters. Mar Freshw Res 53:567-573

Sminkey TR, Musick JA (1996) Demographic analysis of the sandbar shark, Carcharhinus plumbeus, in the western North Atlantic. Fish Bull 94:341-347

Smith SE, Au DW, Show C (1998) Intrinsic rebound potentials of 26 species of Pacific sharks. Mar Freshw Res 49: 663-678

Stevens JD, Bonfil R, Dulvy NK, Walker PA (2000) The effects of fishing on sharks, rays, and chimaeras (chondrichthyans), and the implications for marine ecosystems. ICES J Mar Sci 57:476-494

Sunnucks P, Hales DF (1996) Numerous transposed sequences of mitochondrial cytochrome oxidase I-II in aphids of the genus Sitobion (Hemiptera: Aphididae). Mol Biol Evol 13:510-524

Tamura K, Nei M (1993) Estimation of the number of nucleotide substitutions in the control region of mitochondrial DNA in humans and chimpanzees. Mol Biol Evol 10: 512-526

Tamura K, Peterson D, Peterson N, Stecher G, Nei M, Kumar S (2011) MEGA5: Molecular evolutionary genetics analysis using maximum likelihood, evolutionary distance, and maximum parsimony methods. Mol Biol Evol 28:
2731-2739

> Thompson JD, Higgins DG, Gibson TJ (1994) CLUSTAL W: improving the sensitivity of progressive multiple sequence alignment through sequence weighting, position-specific gap penalties and weight matrix choice. Nucleic Acids Res 22:4673-4680

> Tillett BJ, Meekan MG, Broderick D, Field IC, Cliff G, Ovenden JR (2012a) Pleistocene isolation, secondary introgression and restricted contemporary gene flow in the pigeye shark, Carcharhinus amboinensis across northern Australia. Conserv Genet 13:99-115

> Tillett BJ, Meekan MG, Field IC, Thorburn DC, Ovenden JR (2012b) Evidence for reproductive philopatry in the bull shark Carcharhinus leucas. J Fish Biol 80:2140-2158

Tillett BJ, Field IC, Bradshaw CJA, Johnson G, Buckworth RC, Meekan MG, Ovenden JR (2012c) Accuracy of species identification by fisheries observers in a north Australian shark fishery. Fish Res 127-128:109-115

Toews DPL, Brelsford A (2012) The biogeography of mitochondrial and nuclear discordance in animals. Mol Ecol 21:3907-3930

> Ward RD, Zemlak TS, Innes BH, Last PR, Hebert PDN (2005) DNA barcoding Australia's fish species. Philos Trans R Soc B 360:1847-1857

> White WT (2007) Catch composition and reproductive biology of whaler sharks (Carcharhiniformes: Carcharhinidae) caught by fisheries in Indonesia. J Fish Biol 71: 1512-1540

Whitney NM, Robbins WD, Schultz JK, Bowen BW, Holland $\mathrm{KN}$ (2012) Oceanic dispersal in a sedentary reef shark (Triaenodon obesus): genetic evidence for extensive connectivity without a pelagic larval stage. J Biogeogr 39: 1144-1156

Wright S (1965) The interpretation of population structure by F-statistics with special regard to systems of mating. Evolution 19:395-420 


\section{Appendix 1}

Table A1. Polymorphic sites for mitochondrial DNA ND4 haplotypes defined from Australian and Indonesian waters for the dusky shark Carcharhinus obscurus. (.) indicates the same nucleotide as in haplotype DS1

\begin{tabular}{|c|c|c|c|c|c|c|c|c|c|c|c|c|c|c|c|c|c|c|}
\hline \multirow[t]{2}{*}{ Haplotype } & \multicolumn{18}{|c|}{ Nucleotide polymorphism position (1-857) } \\
\hline & 21 & 34 & 90 & 109 & 124 & 189 & 192 & 199 & 289 & 360 & 400 & 421 & 423 & 453 & 594 & 648 & 649 & 822 \\
\hline DS1 & A & $\mathrm{G}$ & $\mathrm{T}$ & G & G & $\mathrm{T}$ & $\mathrm{T}$ & G & G & $\mathrm{C}$ & $\mathrm{G}$ & $\mathrm{T}$ & $\mathrm{G}$ & $\mathrm{T}$ & $\mathrm{T}$ & $\mathrm{A}$ & $\mathrm{C}$ & $\mathrm{G}$ \\
\hline DS2 & . & . & . & . & . & . & . & . & . & $\mathrm{T}$ & . & . & A & . & . & . & . & . \\
\hline DS3 & . & . & . & . & . & . & . & . & . & . & A & . & A & . & . & . & . & . \\
\hline DS4 & $\mathrm{T}$ & . & . & . & . & . & . & . & . & . & . & . & A & . & . & . & . & . \\
\hline DS5 & . & . & . & A & . & . & . & . & . & . & . & . & $\mathrm{A}$ & . & . & . & . & . \\
\hline DS6 & . & . & . & . & . & . & . & . & . & . & . & . & A & . & . & . & $\mathrm{T}$ & . \\
\hline DS7 & . & . & . & . & . & . & . & . & A & . & . & . & A & . & . & . & . & . \\
\hline DS8 & . & . & $\mathrm{C}$ & . & . & . & . & . & . & . & . & . & $\mathrm{A}$ & . & . & . & . & . \\
\hline DS9 & . & . & . & . & . & . & . & . & . & . & . & . & A & . & . & . & . & . \\
\hline DS10 & . & . & . & . & . & A & . & . & . & . & . & . & $\mathrm{A}$ & . & . & . & . & . \\
\hline DS11 & . & . & . & . & . & A & . & . & . & . & . & $\mathrm{C}$ & A & . & . & . & . & . \\
\hline DS12 & . & . & . & . & . & A & . & . & . & . & . & . & A & . & . & $\mathrm{T}$ & . & . \\
\hline DS13 & . & . & . & . & A & . & . & . & . & . & . & . & A & . & . & . & . & . \\
\hline DS14 & . & . & . & . & . & . & . & . & . & . & . & . & A & . & . & . & . & $\mathrm{A}$ \\
\hline DS15 & . & . & . & . & . & . & $\mathrm{C}$ & . & . & . & . & . & A & $\mathrm{C}$ & . & . & . & . \\
\hline DS16 & . & . & . & . & . & . & $\mathrm{C}$ & A & . & . & . & . & A & $\mathrm{C}$ & . & . & . & . \\
\hline DS17 & . & . & . & . & . & . & $\mathrm{C}$ & . & . & . & . & . & $\mathrm{A}$ & $\mathrm{C}$ & $\mathrm{C}$ & . & . & . \\
\hline DS18 & . & A & . & . & . & . & $\mathrm{C}$ & . & . & . & . & . & A & $\mathrm{C}$ & . & . & . & . \\
\hline
\end{tabular}

Table A2. Polymorphic sites for mitochondrial DNA ND4 haplotypes defined from Australian waters for the sandbar shark Carcharhinus plumbeus. (.) indicates the same nucleotide as in haplotype SB1

\begin{tabular}{|c|c|c|c|c|c|c|c|c|c|c|c|c|}
\hline \multirow[t]{2}{*}{ Haplotype } & \multirow[b]{2}{*}{9} & \multirow[b]{2}{*}{72} & \multirow[b]{2}{*}{120} & \multicolumn{6}{|c|}{ Nucleotide polymorphism position (1-857) } & \multirow[b]{2}{*}{600} & \multirow[b]{2}{*}{650} & \multirow[b]{2}{*}{655} \\
\hline & & & & 160 & 186 & 199 & 209 & 327 & 531 & & & \\
\hline SB1 & $\mathrm{G}$ & $\mathrm{T}$ & $\mathrm{T}$ & $\mathrm{T}$ & A & G & $\mathrm{T}$ & $\mathrm{C}$ & $\mathrm{T}$ & $\mathrm{C}$ & $\mathrm{T}$ & $\mathrm{T}$ \\
\hline SB2 & . & . & $\mathrm{C}$ & . & . & . & $\mathrm{C}$ & . & . & . & . & . \\
\hline SB3 & . & . & . & . & G & . & $\mathrm{C}$ & . & . & . & . & . \\
\hline SB4 & . & . & . & . & . & . & $\mathrm{C}$ & . & . & . & . & . \\
\hline SB5 & A & . & . & . & . & . & $\mathrm{C}$ & $\mathrm{T}$ & . & $\mathrm{T}$ & . & $\mathrm{C}$ \\
\hline SB6 & A & . & . & $\mathrm{C}$ & . & . & $\mathrm{C}$ & $\mathrm{T}$ & . & . & . & $\mathrm{C}$ \\
\hline SB7 & A & . & . & . & . & . & $\mathrm{C}$ & $\mathrm{T}$ & . & . & . & $\mathrm{C}$ \\
\hline SB8 & A & $\mathrm{C}$ & . & . & . & . & $\mathrm{C}$ & $\mathrm{T}$ & . & . & . & $\mathrm{C}$ \\
\hline SB9 & A & . & . & . & . & . & $\mathrm{C}$ & $\mathrm{T}$ & $\mathrm{C}$ & . & . & $\mathrm{C}$ \\
\hline SB10 & A & . & . & . & . & . & $\mathrm{C}$ & $\mathrm{T}$ & $\mathrm{C}$ & . & $\mathrm{C}$ & $\mathrm{C}$ \\
\hline SB11 & A & . & . & . & . & A & $\mathrm{C}$ & $\mathrm{T}$ & C & . & C & C \\
\hline
\end{tabular}

Editorial responsibility: Jim Groombridge, Canterbury, UK
Submitted: May 29, 2013; Accepted: January 10, 2014 Proofs received from author(s): March 30, 2014 